\title{
Antioxidant Properties and Antimicrobial Potential of Aqueous Extract of Basidioma from Lentinus edodes (Berk.) Sing. (Shiitake)
}

\author{
Jéssica Daiane de Melo Macoris ${ }^{1}$, Tatiane Brugnari ${ }^{1}$, Cinthia Gandolfi Boer ${ }^{2}$, \\ Alex Graça Contato ${ }^{1 *}$, Rosane Marina Peralta ${ }^{1}$ and Cristina Giatti Marques de Souza ${ }^{1}$ \\ ${ }^{1}$ Laboratory of Biochemistry of Microorganisms, Department of Biochemistry, State University \\ of Maringá, 87020-900, Maringá, PR, Brazil \\ ${ }^{2}$ Laboratory of Clinical Citology, Department of Clinical Analysis and Biomedicine, State \\ University of Maringá, 87020-900, Maringá, PR, Brazil \\ *Corresponding author
}

\section{A B S T R A C T}

\begin{tabular}{|l|}
\hline K e y w o r d s \\
$\begin{array}{l}\text { L. edodes, } \\
\text { antioxidant assays, } \\
\text { MIC, mushroom, } \\
\text { antimicrobial }\end{array}$ \\
\hline Article Info \\
\hline $\begin{array}{l}\text { Accepted: } \\
\text { 15 August } 2017 \\
\text { Available Online: } \\
\text { 10 September } 2017\end{array}$ \\
\hline
\end{tabular}

Keywords

L. edodes,

ntimicrobial

\section{Introduction}

Reactive species are naturally formed in aerobic metabolism and can cause membrane oxidation and damage to intracellular components such as DNA and proteins. Cells can naturally count on a system of defense against free radicals that protect them from oxidative damage. However, when this system becomes inadequate to protect us efficiently, exogenous antioxidants may be of great importance to prevent or even reduce the damage caused by reactive species (Halliwell, 2012). Several species of mushrooms have been described as a source of antioxidant compounds and due to their important nutritional value the edible mushrooms are attractive as functional food and still as a source of drug and nutraceutical development (Barros et al., 2007; Kalač, 2009).

The Shiitake mushroom (Lentinus edodes) fits taxonomically in the Basidiomycetes class that has approximately 20,300 species, 1,037 genera and 112 families identified. Representatives of this class have been recognized for their therapeutic properties for 
millennia in China, Korea and Japan (Kim \& Kim, 1999). Extracts have been obtained from Shiitake mushrooms using different extraction methods, using polar and apolar solvents versus extraction time, in order to study the bioactive properties of this mushroom. The antioxidant properties of $L$. edodes have been further studied with methanolic, ethanolic or hydroalcoholic extracts, although the aqueous extract is the closest form of which the use of mushrooms in alternative medicine is recommended. The objective of this study was to perform the aqueous extraction of dry basidiomas of $L$. edodes and evaluate their antioxidant and antimicrobial capacity.

\section{Materials and Methods}

\section{Reagents, solvents and standards}

All reagents used were of analytical standard and obtained from Sigma-Aldrich (St. Louis, MO, USA). Culture media were purchased from Difco (Detroit, MI, USA) and Himedia (Mumbai, MH, India).

\section{Tools}

For the preparation of the extract, an incubator cooled with an orbital shaker (Tecnal Laboratory Equipment, Ltda) was used. All spectrophotometric analyzes were performed using the UV-Visible-UV-1800 (Shimadzu, Corp.) spectrophotometer of $1 \mathrm{~nm}$ resolution. For antimicrobial analysis, a SpectraMax M2 Microplate Reader (Molecular Devices, LLC) was utilized.

\section{Preparations of aqueous extract of $L$. edodes}

The dried basidiomas of L. edodes (Shiitake) were purchased at a local supermarket (Maringá-Paraná). For extraction, $20 \mathrm{~g}$ of the ground mushroom were mixed with $200 \mathrm{~mL}$ of sterile distilled water. The material was stirred $(130 \mathrm{rpm})$ for $1 \mathrm{~h}$ at room temperature. After vacuum filtration, the extract was stored in a refrigerator. The residual solid was used for two further extractions as described above. The three volumes of extract were then pooled and lyophilized. The lyophilized material (dry extract) was stored at $-20{ }^{\circ} \mathrm{C}$. For the analysis, the dry extract was weighed and dissolved in distilled water. All tests were performed in triplicate.

\section{Characterization of the aqueous extract of L. edodes}

\section{Amino acids}

Free amino acids and ninhydrin-reactive amines were determined according to the methodology of Yemm and Cocking (1955), with some modifications. An appropriately diluted aliquot of the sample $(1 \mathrm{~mL})$ was added to $0.5 \mathrm{~mL}$ of $0.02 \mathrm{M}$ citrate buffer. A solution of $5 \%$ ninhydrin $(0.2 \mathrm{~mL})$, prepared in ethylene glycol, was added to this mixture followed by $0.1 \mathrm{~mL} \mathrm{KCN}(0.2 \mathrm{mM})$. The mixture was stirred and left in a boiling heat bath for $20 \mathrm{~min}$. Ethanol $60 \%$ (1 mL) was added after cooling. The reading was carried out at $570 \mathrm{~nm}$ and alanine was used as standard.

\section{Total Proteins}

The determination of the total soluble proteins was performed by the method of Bradford (1976). In $250 \mu \mathrm{L}$ aliquots of the extract diluted in water, $2.5 \mathrm{~mL}$ of the Bradford reagent was added. After $5 \mathrm{~min}$ the samples were analyzed at $595 \mathrm{~nm}$. Bovine albumin was used as standard.

\section{Total Sugars}

The methodology described by Yemm and Willis (1954) was used to determine the total soluble sugar content. An aliquot of $1.0 \mathrm{~mL}$ of 
extract diluted in water was added, to which 5 $\mathrm{mL}$ of the anthrone reagent was added. After stirring, the tubes were warmed in a heat-bath for $10 \mathrm{~min}$ and then placed in an ice bath. The absorbance was determined at $625 \mathrm{~nm}$. Glucose was used as standard.

\section{Reducing sugars}

The DNS method (Miller, 1959) was used to determine reducing sugars. In a sample of extract $(0.5 \mathrm{~mL})$, adequately diluted, $0.5 \mathrm{~mL}$ of DNS reagent (3.5-dinitrosalicylic acid) was added. The sample remained in a boiling heat bath for $5 \mathrm{~min}$. The volume of $5 \mathrm{~mL}$ of distilled water was added after the sample was cooled. The reading was at $540 \mathrm{~nm}$. Glucose was used as standard.

\section{Phenolic Compounds}

The concentration of total phenolic compounds in the aqueous extract of $L$. edodes was determined by the method of Folin-Ciocalteu (Singleton \& Rossi, 1965) where $2.0 \mathrm{~mL}$ of properly diluted sample was added $0.3 \mathrm{~mL}$ of sodium carbonate $\mathrm{Na}_{2} \mathrm{CO}_{3}$ 1.9 $\mathrm{M}$ and $100 \mu \mathrm{L}$ of Folin reagent $(1 \mathrm{M})$. The mixture was allowed to stand for $1 \mathrm{~h}$ in the dark and the absorbances were determined at $725 \mathrm{~nm}$. Gallic acid was used as standard. The results were expressed as $\mathrm{mg} / \mathrm{g}$ dry extract of gallic acid equivalents.

\section{Antioxidant activity ABTS Method}

The antioxidant activity of the aqueous extract of $L$. edodes was performed according to Carvajal et al., (2013) with some modifications: the $\mathrm{ABTS}^{\circ+}$ radical was obtained by reaction between ABTS (7.4 $\mathrm{mM}$ ) and potassium persulfate solution (2.6 $\mathrm{mM}$ ). After $12 \mathrm{~h}$ in the dark, stock solution was stored and frozen until use for up to two days. To $1 \mathrm{~mL}$ of this solution was added 59 $\mathrm{mL}$ of methanol and the absorbance was corrected to $1.1 \pm 0.01$. The ability to scavenging the $\mathrm{ABTS}^{\circ+}$ radical was verified by mixing $2850 \mu \mathrm{L}$ of the $\mathrm{ABTS}^{\circ+}$ solution with $150 \mu \mathrm{L}$ of the aqueous extract in different concentrations. The mixture remained in the dark for $2 \mathrm{~h}$ and absorbance was read at $734 \mathrm{~nm}$ (Abs sample). Distilled water was used in place of the sample as control (Abs control). The butylated hydroxytoluene-BHT $(0.02 \%)$ was used as a positive control. The antioxidant capacity was calculated using the following equation:

Scavenging ABTS radical $(\%)=\frac{\text { Abs control }- \text { Abs sample }}{\text { Abs control }} \times 100$

The concentration of extract that promotes $50 \%$ reduction $\left(\mathrm{EC}_{50}\right)$ of the $\mathrm{ABTS}^{\circ+}$ radical was calculated from the ABTS capture activity graph versus extract concentration.

\section{DPPH Method}

It was performed as described in Carvajal et al., (2013). Various concentrations of aqueous extract $(150 \mu \mathrm{L})$ were mixed with $2850 \mu \mathrm{L}$ of the radical DPPH solution $(0.1 \mathrm{mM})$. The mixture was left for $1 \mathrm{~h}$ at room temperature in the dark and subsequent to absorption at $515 \mathrm{~nm}$. Water was used as a negative control in place of the extract and BHT $(0.02 \%)$ as a positive control. The ability to sequester the DPPH radical was calculated using the following equation:

Scavenging DPPH radical $(\%)=\frac{\text { Abs control }- \text { Abs sample }}{\text { Abs control }} \times 100$

The concentration of extract that promotes $50 \%$ reduction $\left(\mathrm{EC}_{50}\right)$ of the DPPH radical was calculated from the ABTS capture activity graph versus extract concentration.

\section{Evaluation of the chelating activity of $\mathrm{Fe}^{+2}$}

The analysis was performed according to the methodology described by Carvajal et al., 
(2013). The chelating activity of the ferrous ion was determined using $0.7 \mathrm{~mL}$ extract in different concentrations, diluted in $0.7 \mathrm{~mL}$ distilled water and mixed with $0.175 \mathrm{~mL}$ $\mathrm{FeCl}_{2}(0.5 \mathrm{mM})$. Absorbance $\left(\mathrm{Abs}_{0}\right)$ was determined at $550 \mathrm{~nm}$. After addition of 0.175 $\mathrm{mL}$ ferrozine $(0.5 \mathrm{mM})$ the reaction was started.

The mixture was then stirred vigorously and left at room temperature for $20 \mathrm{~min}$. Absorbance $\left(\mathrm{Abs}_{1}\right)$ was determined at the same wavelength. Distilled water was used as control (Abs control). EDTA $(0.5 \mathrm{mM})$ was used as a positive control. The percent inhibition of the $\mathrm{Fe}^{+2}$-ferrozin formed was calculated as follows:

Activity chelating $(\%)=\frac{A b s \text { control }-\left(A b s_{1}-A B s_{0}\right)}{A b s \text { control }} \times 100$

The concentration of extract that promoted $50 \%$ reduction $\left(\mathrm{EC}_{50}\right)$ of the chelating activity of $\mathrm{Fe}^{+2}$ was calculated from the ABTS capture activity graph versus extract concentration.

\section{Evaluation of the reducing power}

The reducing power assay was performed using the method described by Soares et al., (2009), with some modifications. Different concentrations of extract were prepared. For each $1.0 \mathrm{~mL}$ of extract $2.5 \mathrm{~mL}$ of phosphate buffer (0.2 M, pH 6.6) and $2.5 \mathrm{~mL}$ of potassium ferricyanide (1\%) was added.

The mixture was incubated at $50{ }^{\circ} \mathrm{C}$ for 20 min. After this time, $2.5 \mathrm{~mL}$ of trichloroacetic acid $(10 \%)$ was added to the mixture. The sample was then centrifuged at $6000 \mathrm{rpm}$ for $10 \mathrm{~min} ; 2.5 \mathrm{~mL}$ of the supernatant was mixed with $2.5 \mathrm{~mL}$ of distilled water and $0.25 \mathrm{~mL}$ of $\mathrm{FeCl}_{3}$ solution $(0.1 \%)$. The absorbance was measured at $700 \mathrm{~nm}$. A negative control was prepared without extract. The BHT was used as a positive control.

\section{Antimicrobial activity Microorganisms}

The microorganisms were kindly provided by Dr. Benício Alves Abreu Filho of the Department of Basic Health Sciences DBS/UEM. The strains used were Aeromonas hydrophila ATCC 7966, Bacillus subtilis ATCC 6051, Escherichia coli ATCC 25922, Klebisiella pneumoniae ATCC 700603, Pseudomonas aeruginosa ATCC 15442, Salmonella enterica ATCC 13076, Staphylococcus aureus ATCC 25923, Candida albicans ATCC 10231 and Saccharomyces cerevisiae (commercial Sigma). The microorganisms were activated in Müller Hilton agar for bacteria and Sabouraud agar for fungi and incubated at 36 ${ }^{\circ} \mathrm{C}$ for $24 \mathrm{~h}$.

\section{Minimum inhibitory concentration (MIC)}

The antimicrobial activity was determined based on the well microdilution methodology described in NCCLS (National Committee for Clinical Laboratory Standards [NCCLS], 2002) and NCCLS (National Committee for Clinical Laboratory Standards [NCCLS], 2003), with some modifications. The test basically consisted in preparing various concentrations of the extract in broth medium of the microorganisms and mixing them with an inoculum of the microorganism of interest, previously diluted in the same broth.

The extracts were prepared taking into account the final dilution in the inoculum, which in turn was adjusted to the final concentration of $1.0 \times 10^{5} \mathrm{CFU} / \mathrm{mL}$ for bacteria and $2.5 \times 10^{3} \mathrm{CFU} / \mathrm{mL}$ for fungi. The plates were incubated for $24 \mathrm{~h}$ in an oven at $35{ }^{\circ} \mathrm{C}$ and then the reading was carried out at $630 \mathrm{~nm}$.

The MIC was determined as the lowest extract concentration capable of inhibiting the growth of the microorganism. 
Minimum concentration

The Minimum Bactericidal Concentration (MBC) was determined based on the methodology of Santurio et al., (2007), where the wells that did not have visible bacterial growth, an aliquot of $10 \mu \mathrm{L}$ was removed and seeded on the surface of Müller Hilton agar.

The plates were incubated at $36{ }^{\circ} \mathrm{C}$ for $24 \mathrm{~h}$. The MBC was defined as the concentration of the extract capable of causing the death of the inoculum.

To determine the Minimum Fungicidal Concentration (MFC), an aliquot of $10 \mu \mathrm{L}$ of each well of the microplate was seeded on plates containing Sabouraud dextrose agar, which were incubated for $24 \mathrm{~h}$ at $28^{\circ} \mathrm{C}$.

The MFC was defined as the concentration capable of causing the death of the inoculum. Antibiotics (gentamicin and streptomycin) and antifungal (fluconazole) were used as positive controls.

\section{Statistical analysis}

Data analysis was performed using GraphPad Prism ${ }^{\circledR}$ software version 5.0 (Graph Pad Software, San Diego, USA). The significance criterion adopted was $\mathrm{P}<0.05$ and all values were expressed as the mean of the independent experiments.

Sample concentrations that resulted in 50\% antioxidant activity or absorbance $\left(\mathrm{EC}_{50}\right)$ were calculated from percentages of antioxidant activity (ABTS, DPPH and ferrous ion chelating activity) or absorbance at $700 \mathrm{~nm}$ (reducing power) against sample concentrations, through linear regression.

The Pearson correlation coefficient was obtained using the same program.

\section{Results and Discussion}

\section{Productivity and chemical composition of the extract}

The aqueous extract obtained from the fruiting body of the L. edodes mushroom presented yield of $25 \%$. The foods rich in phenolic compounds exhibit higher yields in the extraction process with polar solvents, due to their solubility (Tsai et al., 2009; Silva and Jorge, 2011). The Table 1 compares extracts obtained from $L$. edodes using solvents other than water. Although similar or even higher yields can be obtained with alcoholic or hydroalcoholic extractions (Silva and Jorge, 2011; Cheung et al., 2003; Yang et al., 2002), water extraction is the closest to the form of consumption, similar to the preparation of medicinal teas. Extraction using nonpolar compounds shows low yields (Table 1) and it is more interesting to use these solvents for serial extractions.

The analysis of the aqueous extract of the basidioma of $L$. edodes showed the presence of amino acids, carbohydrates, proteins and phenolics (Table 2). The concentration of phenolic compounds found in the extract was similar to that found by some researchers using the same extraction method. However, the studies show a great difference in the concentrations obtained. The differences can be due the time of extraction, temperature and composition of the basidiomas, which varies according to some factors, such as age of the fruiting body, substrate for production and cultivation conditions (Mattila et al., 2001). The evaluation of the extract regarding the other components also showed differences between the values found and other findings in the literature. Zhang et al., (2003) found the value of $373.19 \pm 8.51 \mathrm{mg}$ protein per gram of dry extract obtained from the hot aqueous extraction of the mushroom residue after ethanol extraction. The amount of total 
soluble sugars found in this study was similar to that found in our study, $365.18 \pm 39.18$ $\mathrm{mg} / \mathrm{g}$ dry extract.

Antioxidant properties of the aqueous extract of the basidioma of $L$. edodes

\section{ABTS and DPPH}

The ability to act as an antioxidant by scavenging free radicals and reactive oxygen species is considered the best propertie described for polyphenols (Jung et al., 2003).

The antioxidant properties of the extract were evaluated through four methods (Figure 1). The free radical sequestration, analyzed by the ABTS and DPPH methods, occurred at the different extract concentrations tested (Fig. 1A and Fig. 1B). The antioxidant activity increased with the increase of the sample concentration, totalizing almost $100 \%$ of $\mathrm{ABTS}^{\circ+}$ radical scavenging at $5 \mathrm{mg} / \mathrm{mL}$ extract (Fig. 1A). This same concentration was able to cause approximately $62 \%$ of DPPH radical scavenging. In this test, the antioxidants that are able to reduce the DPPH radical (purple colored) for the non-radical form (yellow colored) (Chowdhury et al., 2015).

\section{Ferrous ion chelating activity and reducing power}

Radicals can be formed, initially, from the action of transition metals. In stabilizing of transition metals in the living systems, chelating agents are able to inhibit the generation of radicals, also reducing damage to the organism. In the method of the chelating activity of the ferrous ion, ferrozine forms a complex with $\mathrm{Fe}^{+2}$ resulting in a reddish coloration, being that the presence of chelating agents in the reaction can prevent the formation of ferrozine- $\mathrm{Fe}^{+2}$ complex resulting in decreased staining. The ability of the aqueous extract of $L$. edodes to chelate the ferrous ion is shown in Fig. 1C. Low concentrations of the extract were sufficient to cause the chelation of $92 \%$ of the ions present in solution.

In the test of reducing power, the yellow coloration of the solution changes to several shades of green and blue, depending on the reducing power of each compound (Barros et al., 2007). The presence of reducers causes the conversion of the $\mathrm{Fe}^{+3}$ /ferricyanide to the ferrous form; measuring the apparent staining at $700 \mathrm{~nm}$ it is possible to determine the concentration of $\mathrm{Fe}^{+}{ }^{2}$. Reducing power increases with absorbance. The reducing power of the extracts of the basidioma of $L$. edodes is represented by Fig. 1D. In this test, $166 \mathrm{mg} / \mathrm{mL}$ extract showed the absorbance of 0.850 .

\section{EC50 values and correlation with phenolic compounds}

The $\mathrm{EC}_{50}$ values found for the antioxidant activity tests are summarized in Table 3 . The use of more than one method to evaluate the antioxidant activity of extracts of different types of foods, takes into account that different antioxidant compounds can act in vivo through different mechanisms (Carvajal et al., 2013). The $\mathrm{EC}_{50}$ value obtained by the ABTS method was twice as low as the concentration required to scavenging $50 \%$ of the DPPH radical (Table 3). High $\mathrm{EC}_{50}$ values were found for chelating ion activity and reducing power (Table 3 ).

The antioxidant activity of fruits, juices, wines, mushrooms and other foods can be associated with the presence of polyphenols, vitamins, carotenoids and minerals. In relation with the antioxidant properties of mushroom extracts, compounds such as organic acids (Kayashima and Katayama, 2002), phenolics (Cheung and Cheung, 2005), polysaccharides 
(Thetsrimuang et al., 2011) and peptides (Xie et al., 2008) have been reported as antioxidants, but polyphenols are the compounds that have been most associated with these properties (Cheung et al., 2003). In our work a strong correlation was found between the phenolic concentration and the antioxidant activity evaluated by the four study methods employed (Table 3). However, because it is a crude extract, the other compounds whose concentrations were determined in this study may also present some type of antioxidant activity. As antioxidant activity may be a property found in different types of molecules, the isolation and characterization of the components of the extract would lead to a better understanding of the molecules responsible for the antioxidant activity presented by the aqueous extract of L. edodes.

Table.1 Obtaining extracts of basidioma from L. edodes

\begin{tabular}{|c|c|c|c|c|}
\hline $\begin{array}{l}\text { Extraction } \\
\text { conditions }\end{array}$ & Yield (\%) & $\begin{array}{l}\text { Total phenolics } \\
(\mathrm{mg} / \mathrm{g})\end{array}$ & $\begin{array}{l}\text { Extraction } \\
\text { time }\end{array}$ & Reference \\
\hline Water & 25 & $5.66 \pm 0.057$ & $1 \mathrm{~h}^{*}$ & This study \\
\hline Water & 29.92 & $120.44 \pm 1.09$ & $30 \mathrm{~min}$. & SILVA \& JORGE, 2011 \\
\hline Water & $16.2 \pm 0.80$ & $1.33 \pm 0.04$ & $3 \mathrm{~h}$ & $\begin{array}{l}\text { CHEUNG; CHEUNG; } \\
\text { OOI, } 2003\end{array}$ \\
\hline $\begin{array}{c}\text { Ethanol/Water } \\
(1: 1)\end{array}$ & 23.44 & $45.33 \pm 0.61$ & $30 \mathrm{~min}$. & SILVA \& JORGE, 2011 \\
\hline Ethanol & 11.46 & $20.00 \pm 0.22$ & $30 \mathrm{~min}$. & SILVA \& JORGE, 2011 \\
\hline $\begin{array}{c}\text { Methanol/water } \\
\text { (1:1) }\end{array}$ & 29.65 & $43.13 \pm 0.66$ & $30 \mathrm{~min}$. & SILVA \& JORGE, 2011 \\
\hline Methanol & 18.8 & $6.27 \pm 0.02$ & $24 \mathrm{~h}$ & YANG; LIN; MAU, 2002 \\
\hline Methanol & $33.5 \pm 1.75$ & $4.79 \pm 1.2$ & $3 \mathrm{~h}$ & $\begin{array}{c}\text { CHEUNG; CHEUNG; } \\
\text { OOI, } 2003\end{array}$ \\
\hline Petroleum ether & $2.4 \pm 0.08$ & $0.44 \pm 0.07$ & $3 \mathrm{~h}$ & $\begin{array}{l}\text { CHEUNG; CHEUNG; } \\
\text { OOI, } 2003\end{array}$ \\
\hline Ethyl acetate & $3.65 \pm 0.18$ & $0.033 \pm 0.01$ & $3 \mathrm{~h}$ & $\begin{array}{c}\text { CHEUNG; CHEUNG; } \\
\text { OOI, } 2003\end{array}$ \\
\hline
\end{tabular}

*With the residue from the first extraction plus two extraction cycles were performed.

Table.2 Content of the major constituents of the aqueous extract of L. edodes

\begin{tabular}{lc}
\hline Constituents & $\begin{array}{c}\text { Content } \\
(\mathrm{mg} / \mathrm{g} \text { dry extract) }\end{array}$ \\
\hline Amino acids and ninhydrin-reactive amines $^{\mathrm{a}}$ & $28.10 \pm 0.86$ \\
Total carbohydrates $^{\mathrm{b}}$ & $378.23 \pm 8.46$ \\
Reducing carbohydrates $^{\mathrm{b}}$ & $89.95 \pm 3.58$ \\
Non-reducing carbohydrates $^{\mathrm{b}}$ (by difference) $^{\mathrm{c}}$ & $280.28 \pm 4.94$ \\
Total phenolics $^{\mathrm{c}}$ & $5.66 \pm 0.057$ \\
Total proteins $^{\mathrm{d}}$ & $171.65 \pm 8.86$ \\
\hline
\end{tabular}

*The results were expressed as mean \pm standard deviation $(n=3)$. ${ }^{a}$ alanine equivalents; ${ }^{b}$ glucose equivalents; ${ }^{\mathrm{c}}$ gallic acid equivalents; ${ }^{\mathrm{d}}$ albumin equivalents. 
Table.3 Antioxidant activity of the aqueous extract of L. edodes $\left(\mathrm{EC}_{50}\right)$ and Pearson's correlation coefficient $(r)$ between extract concentrations and total phenolics

\begin{tabular}{lclll}
\hline Methods & $\mathrm{EC}_{50}$ & Pearson $r$ & $\mathrm{R}^{2}$ & Meaningfulness \\
\hline ABTS & $0.191 \pm 0.001$ & 0.9801 & 0.9606 & $* *$ \\
DPPH & $0.400 \pm 0.004$ & 0.9989 & 0.978 & $* * *$ \\
Ferrous ion chelating activity & $1.488 \pm 0.004$ & 0.9552 & 0.912 & $*$ \\
Reducing power & $0.574 \pm 0.001$ & 0.9584 & 0.9185 & $*$ \\
\hline
\end{tabular}

*Significant $(\mathrm{P}>0.01 \mathrm{e}<0.05)$; **very significant $(\mathrm{P}>0.001 \mathrm{e}<0.01)$; ***extremely significant $(\mathrm{P}<0.001)$.

Fig.1 Antioxidant activity of the aqueous extract of the basidioma of L. edodes. A: ABTS; B: DPPH; C: chelating activity of $\mathrm{Fe}^{+2}$; D: reducing power

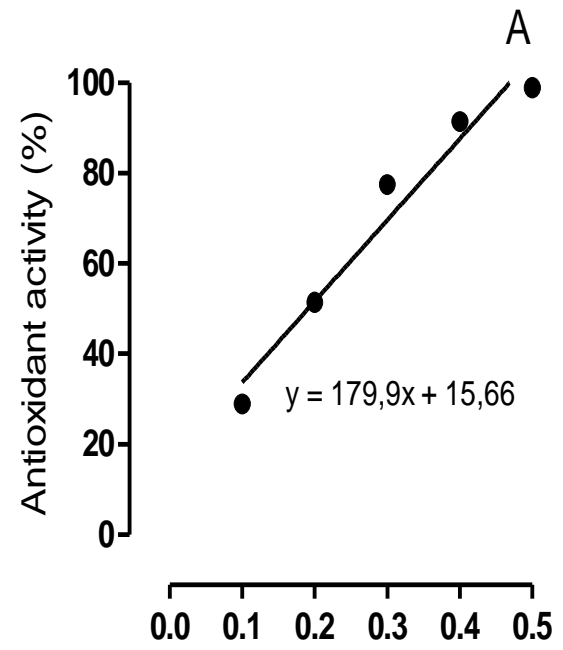

Concentration $(\mathrm{mg} / \mathrm{mL})$

C

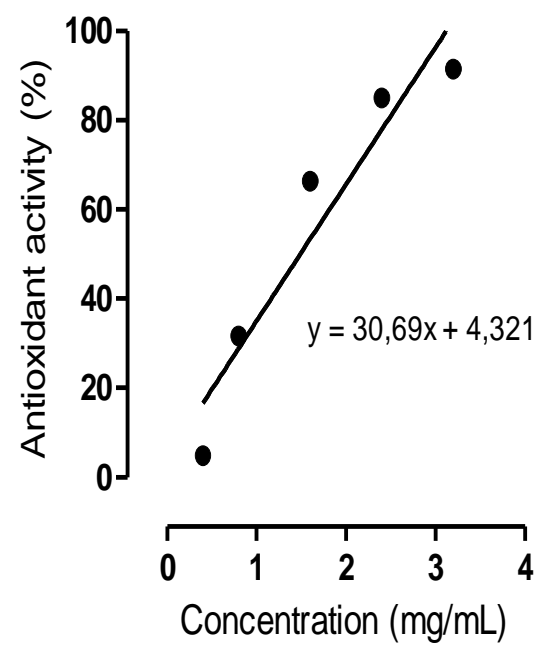

B
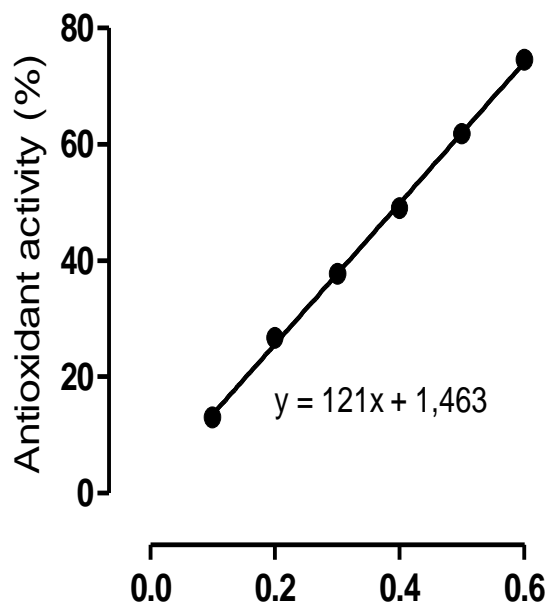

Concentration $(\mathrm{mg} / \mathrm{mL})$
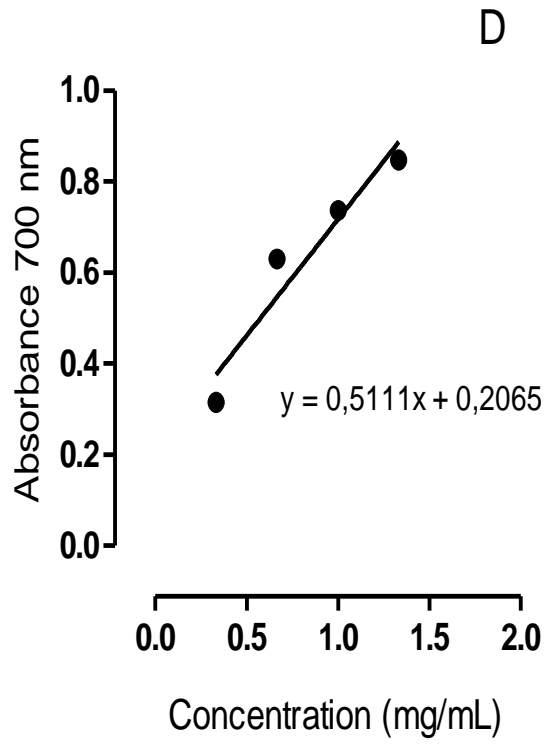
Fig.2 Antimicrobial activity of the aqueous extract of L. edodes. MIC (Minimum Inhibitory Concentration); MBC (Minimum Bactericidal Concentration); MFC (Minimum Fungicidal Concentration)

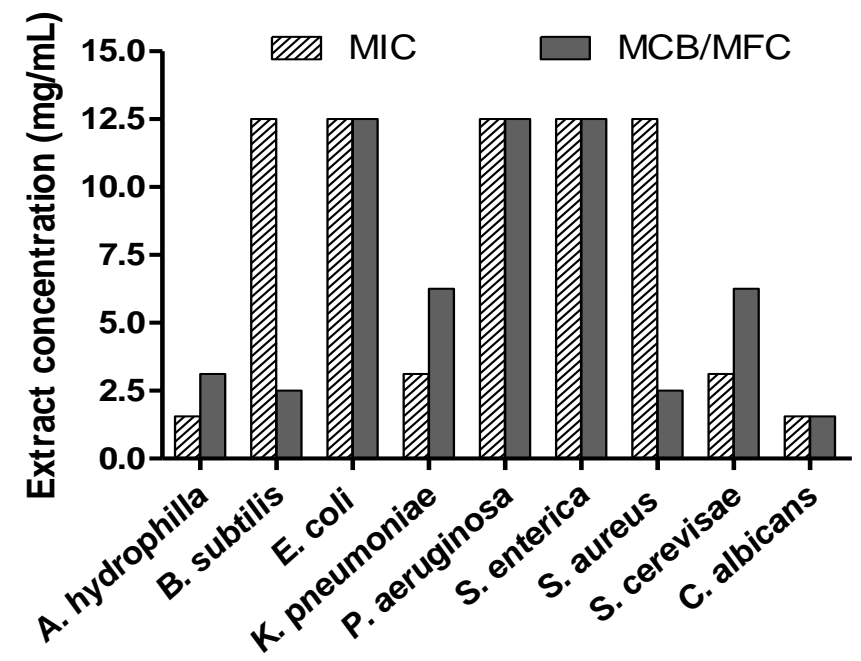

Antimicrobial potential of aqueous extract of basidioma of $L$. edodes

The evaluation of the antimicrobial activity of the extract was performed using the microdilution method in wells. The minimum inhibitory concentration and the minimum bactericidal/fungicidal concentration are showed in the Figure 2. The most sensitive bacteria/ fungi were, in the following order, A. hydrophila, $C$. albicans, $K$. pneumoniaea and $S$. cerevisae with the lowest values of MIC. The other microorganisms tested had the same MIC values $(12.5 \mathrm{mg} / \mathrm{mL}$ extract). In relation to MCB the most sensitive bacteria were A. hydrophilla, B. subtilis and S. aureus with values of $3.12 ; 3.0$ and $2.50 \mathrm{mg} / \mathrm{mL}$, respectively. Low MFC values $(1.56 \mathrm{mg} / \mathrm{mL})$ were found for C. albicans.

Extracts from various species of mushrooms have been evaluated for the ability to inhibit the growth of clinically important bacteria (Vamanu, 2012) and different types of extract obtained from basidiomas of L. edodes have shown antimicrobial potential. The study conducted by Hirasawa et al., (1999) showed that three different types of extracts obtained from dry basidiomas of $L$. edodes had action on oral cavity bacteria using the microdilution method in wells. The extracts of chloroform, ethyl acetate and water had their lowest inhibitory concentrations below $50 \mathrm{mg} / \mathrm{mL}$ against different species of Gram-positive and Gram-negative bacteria. Contrasting with these results, microorganisms of the most common genera, but also clinically important (Enterococcus, Staphylococcus, Escherichia, Bacillus and Candida) were resistant. Among the species evaluated in our study, $C$. albicans, $S$. aureus, $S$. enterica, E. coli and $B$. subtillis were sensitive to dosages lower than $12.5 \mathrm{mg} / \mathrm{mL}$ extract.

The aqueous extract of dried basidiomas of $L$. edodes showed to have antioxidant capacity against different study methods with strong correlation for phenolic compounds. The antimicrobial activity tested against different bacteria and the yeast $C$. albicans resulted in low extract concentration values that inhibited the growth or caused the death of microorganisms of clinical importance, which means that the $L$. edodes bioactives once 
isolated can be evaluated for future biotechnological applications.

\section{Acknowledgements}

Conselho Nacional de Desenvolvimento em Pesquisa (CNPq), Coordenação de Aperfeiçoamento de Pessoal de Nível Superior (Capes) and Fundação Araucária (FA) for financial support.

\section{References}

Barros, L., Ferreira, M. J., Queirós, B., Ferreira, I. C. F. R. and Baptista, P. 2007. Total phenols, ascorbic acid, $\beta$ carotene and lycopene in Portuguese wild edible mushrooms and their antioxidant activities. Food Chemistry. 103 (2): 413-419.

Bradford, M. M. 1976. A rapid and sensitive method for the quantitation of microgram quantities of protein utilizing the principle of protein-dye binding. Analytical Biochemical. 72 (12): 248-254.

Carvajal, A. E. S. S., Koehnlein, E. A., Soares, A. A., Eler, G. J., Nakashima, A. T. A., Bracht, A. and Peralta, R. M. 2013. Bioactives of fruiting bodies and submerged culture mycelia of Agaricus brasiliensis (A. blazei) and their antioxidant properties. LWT - Food Science and Technology. 46 (2): 493 499.

Cheung, L. M. and Cheung, P. C. K. 2005. Mushroom extracts with antioxidant activity against lipid peroxidation. Food Chemistry. 89 (3): 403-409.

Cheung, L. M., Cheung, C. K. and Ooi, V. E. C. 2003. Antioxidant activity and total phenolics of edible mushroom extracts. Food Chemistry. 81 (2): 249-255.

Chowdhury, M. M. H., Kubra, K. and Ahmed, S. R. 2015. Screening of antimicrobial, antioxidant properties and bioactive compounds of some edible mushrooms cultivated in Bangladesh. Annals of Clinical Microbiology Antimicrobials. 14 (8): 2-6.

Halliwell, B. 2012. Free radicals and antioxidants: updating a personal view. Nutrition Reviews. 70 (5): 257-265.

Hirasawa, M., Shouji, N., Neta, T., Fukushima, K. and Takada, K. 1999. Three kinds of antibacterial substances from Lentinus edodes (Berk.) Sing. (Shiitake, an edible mushroom). International Journal of Antimicrobial Agents. 11 (2): 151-157.

Jung, M. J., Chung, H. Y., Choi, J. H. and Choi, J. S. 2003. Antioxidant principles from the needles of red pine, Pinus densiflora. Phytotherapy Research. 11 (9): 1064-1068.

Kalač, P. 2009. Chemical composition and nutritional value of European species of wild growing mushrooms: A review. Food Chemistry. 113 (1): 9-16.

Kayashima, T. and Katayama, T. 2002. Oxalic acid is available as a natural antioxidant in some systems. Biochimica et Biophysica Acta. 1573 (1): 1-3.

Kim, H. W. and Kim, B. K. 1999. Biomedical triterpenoids of Ganoderma lucidum (Curt.: Fr.) P. Karst. (Aphyllophoromycetideae). International Journal of Medicinal Mushrooms. 1(2): 121-138.

Mattila, P., Könko, K., Eurola, M., Pihlava, J. M., Astola, J., Vahteristo, L., Hietaniemi, V., Kumpulainen, J., Valtonen, M. and Piironen, V. 2001. Contents of vitamins, mineral elements, and phenolic compounds in cultivated mushrooms. Journal of Agricultural and Food Chemistry. 49 (5): 2343-2348.

Miller, G.L. 1959. Use of dinitrosalicylic acid reagent for determination of reducing sugar. Analytical Chemistry. 31 (3): 426-428. 
NCCLS (National Committee for Clinical Laboratory Standards). Methods for dilution antimicrobial susceptibility tests for bacteria that grow aerobically; approved standard. NCCLS document M7-A6. 6 ed. NCCLS, 2003.

NCCLS (National Committee for Clinical Laboratory Standards). Reference method for broth dilution antifungal susceptibility testing of yeasts; approved standard. NCCLS document M27-A2. 2 ed. NCCLS, 2002.

Santurio, M. J., Santurio, D. F., Pozzati, P., Moraes, C., Franchin, P. R., and Alves, S. H. (2007). Atividade antimicrobiana dos óleos essenciais de orégano, tomilho e canela frente a sorovares de Salmonella de origem avícola. Ciência Rural. 37 (3): 803-808.

Silva, A. C., and Jorge, N. 2011. Antioxidant properties of Lentinus edodes and Agaricus blazei extracts. Journal of Food Quality. 34 (6): 386-394.

Singleton, V.L. and Rossi, J.A. 1965. Colorimetry of total phenolics with phosphomolybdic-phosphotungstic acid reagents. American Journal Enology and Viticulture. 16: 144-158.

Soares, A. A., Souza, C. G. M., Daniel, F. M., Ferrari, G. P., Costa, S. M. G. and Peralta, R. M. 2009. Antioxidant activity and total phenolic content of Agaricus brasiliensis (Agaricus blazei Murril) in two stages of maturity. Food Chemistry. 112 (4): 775-781.

Thetsrimuang, C., Khammanuang, S. and Sarnthima, R. 2011. Antioxidant activity of crude polysaccharides from edible fresh and dry mushroom fruiting bodies of Lentinus sp. strain RJ-2. International Journal of Pharmaceutics. 7 (1): 58-65.

Tsai, S. Y., Huang, S. J., Lo, S. H., Wu, T. P., Lian, P. Y. and Mau, J. L. 2009. Flavour components and antioxidant properties of several cultivated mushrooms. Food Chemistry. 113 (2): 578-584.

Vamanu, E. 2012. In vitro antimicrobial and antioxidant activities of ethanolic extract of lyophilized mycelium of Pleurotus ostreatus PQMZ91109. Molecules. 17 (4): 3653-3671.

Xie, Z., Huang, J., Xu, X. and Jin, Z. 2008. Antioxidant activity of peptides isolated from alfalfa leaf protein hydrolysate. Food Chemistry. 111 (2): 370-372.

Yang, J. H., Lin, H. C. and Mau, J. L. 2002. Antioxidant properties of several commercial mushrooms. Food Chemistry. 77 (2): 229-235.

Yemm, E. W. and Cocking, E. C. 1955. The determination of amino-acids with ninhydrin. Analyst. 80: 209-214.

Yemm, E. W. and Willis, A. J. 1954. The estimation of carbohydrates in plant extracts by anthrone. Biochemical Journal. 57 (3): 508-514.

Zhang, N., Chen, H., Zhang, Y., Xing, L., Li, S., Wang, X. and Sun, Z. 2015. Chemical composition and antioxidant properties of five edible Hymenomycetes mushrooms. International Journal of Food Science and Technology. 50 (2): 465-471.

\section{How to cite this article:}

Jéssica Daiane de Melo Macoris, Tatiane Brugnari, Cinthia Gandolfi Boer, Alex Graça Contato, Rosane Marina Peralta and Cristina Giatti Marques de Souza. 2017. Antioxidant Properties and Antimicrobial Potential of Aqueous Extract of Basidioma from Lentinus edodes (Berk.) Sing. (Shiitake). Int.J.Curr.Microbiol.App.Sci. 6(10): 3757-3767. doi: https://doi.org/10.20546/ijcmas.2017.610.464 